\title{
Case Study on Cultural and Creative Commodity Development and Design Based on Value Creation
}

\author{
Zeling Zheng \\ Department of Film and TV Technology \\ Fuzhou University of International Studies and Trade
}

Fujian, China

\begin{abstract}
This paper aims to report a successful case of cultural and creative commodity development and design, apply value creation theory in practical process of development and design, take gold orchid cultural and creative product developed and designed from living orchid as a biotechnology product as the object of study, and adopt interdisciplinary cooperative research, study and design between industry and school. This paper consists of three parts. First, it discusses application of value creation theory in cultural and creative products. Then, it describes research, development and design process of cultural and creative orchid product as an individual case. Finally, it summarizes industry-academy cooperation and culture creativity evaluation index. Main contribution of this paper is successful application of value creation. It is a set of concise reflection on technology in research, development and design of cultural and creative products.
\end{abstract}

Keywords-cultural and creative products; industry-academy cooperation; value creation

\section{RESEARCH MOTIVE AND PURPOSE}

After high-tech hard economy, cultural and creative industry becomes the most money drawing industry in soft economy during evolution of knowledge economy. Various countries in the world try their utmost to promote cultural and creative industry. Governments of various countries make source of law and policies to support development of cultural and creative industry one after another. For instance, principle axis of the 12th Five-Year Plan policy brought forward by China in 2010 is developing cultural and creative industry. In the same year, Taiwan passes Cultural and Creative Industry Development Law -- Cultural and Creative Law for short in order to determine development direction and enforcement rules of cultural and creative industry. However, how to combine technology and art to design commodities? How to conduct research and design through industry-academy cooperation? Which kind of operation mode should be taken to expand value connecting with market? Due to these questions, this case study uses industry-academy cooperation to transform living orchid planted and cultivated by biotechnology into gold orchid cultural and creative product by electroforming of gold. This paper's purpose is to report a successful case of cultural and creative commodity development and design, apply value creation theory in the practical process of development and design, take gold orchid cultural and creative product developed and designed from living orchid as a biotechnology product as the object of study, and adopt interdisciplinary cooperative research, study and design between industry and school.

\section{VALUE CREATION PRINCIPLE}

Why does value need to be created? Webster's Dictionary refers to value as money's worth or can be traded for some other things, like commodity or labor. Xue Qi (Economic Daily in 2006) thinks that every valuable product in market has its price. On the contrary, value is a kind of attitude toward life and a kind of perspective, belief, pursuit and insistence of beautiful things. During its sublimation process, or when we share it with other people, price comes into being. These industrial people, entrepreneurs or businessmen make our life happier, more fruitful and merrier. They are creating value. In $2005, \mathrm{Hu}$ Wenfeng pointed out that price is always regarded as an important element of market competition. However, client's affirmation of product value is the most changeful. Sometimes, even reduced price fails to arouse clients' interest. Recently, American enterprises import client-oriented value creation successively in improving competition. Namely, they attach great importance to creating useful value for clients. Use brand value formula to analyze and view personal computer industry. Dell personal computer marketing-based brand creates higher enterprise value than personal computer manufacturers of IBM and HP.

Industrial Technology Research Institute advocates that value creation is a set of concise thinking technology, the solution to problems in research and development lies on clients, and we should start from knowing clients' needs, think in the perspective of clients, help clients find out solutions, and use differentiation analysis to create the highest profit and value. Only when we change our perspective of viewing problems and start from finding out clients' needs, can we reframe problems in a brand new way. Only such correct solution is meaningful. Only by this, can we make breakthrough. Value creation is upstream, including knowing the market, innovation, research and exhibition, and intellectual property manufacturing. Realization of value is downstream, including distribution, service, brand positioning, popularity and image. If we fail to distribute products to consumers or fail to provide good services, it is impossible to realize value no matter how good the product is. Realization of value relies on control of management and marketing costs, 
increasing operation efficiency and improving service satisfaction.

Value creation management is evaluated as the management concept which can satisfy enterprise party the most and the most integrated management system in the 21st century by Fortune Magazine, especially when facing new competitive environment and conducting reform management. According to American Stern Stewart Company's research report of five years tracing of 65 companies applying value creation management in America, the result shows as follows: Return on equity of enterprises investing in value creation management is $49 \%$ higher than companies of the same type which do not conduct value creation management. In 2007, He Yueyuan points out that there are three processes in value creation: Physical process: We only pay attention to physical property, commodity production and physical process of commodity. Engineering process: Based on physical process of commodity production, take an enterprise as inspection unit and regard cost and profit as the objective. The value here refers to equilibrium price. Sociology process: Based on adequate understanding of human nature and society, correctly evaluate value and its origin, take healthy development of the entire society as the objective and lead the society in creating more abundant real value. Its essence is a philosophical problem and also a problem of value. This paper is partial to argument of the first and the third process and thinks that creative industry can create production value, drive vigorous development of various industries and produce higher economic profit and value. Four steps of value creation include exploring unsatisfied needs, solution, surpassing differentiation and result benefit, and they are called NSDB in short. Promotion knowledge of value creation is in the following "Table I".

TABLE I. CREATIVITY AND VALUE CREATION

\begin{tabular}{|l|l|}
\hline \multicolumn{1}{|c|}{ Creativity work connotation } & \multicolumn{1}{c|}{ NSDB } \\
Value creation NSDB
\end{tabular}

\section{AN INDIVIDUAL CASE OF RESEARCH, DEVELOPMENT AND DESIGN-GOLD ORCHID CULTURAL AND CREATIVE PRODUCT}

According to definition of United Nations Educational, Scientific and Cultural Organization, cultural industry is suitable for those contents with intangible culture as essence. The industry combined with commercialization after creation and production can be regarded as creative industry, sunrise or future oriented industry, or content industry. This research uses craft and design to plate gold on living orchid planted and cultivated by biotechnology to make gold orchid cultural and creative products and to create new value of creativity industry.

Definition of creative gold orchid product series: It refers to products with orchid as theme and using two directions of new product development series creative commodity in marketing management theory: breadth and depth. First: Depth series refer to stumpy orchids experiencing surface treatment by gold electroforming technology to prolong orchid's life and they can also be called gold orchids. Or plate gold on sheet orchid and combine with costume, pendants and jewelry to make innovative gold orchid. Second: In breadth aspect, further imitate appearance, pattern, color or fragrance of orchid, develop and design fancy soap and cosmetics called cam ranh soap, or add processed leaves of orchid plant in soap, or extract orchid essence and add it in cosmetics, apply for patent for invention and further use intelligent embroidery and sewing to design three-dimensional gold orchid called creative gold orchid.

\section{A. Gold orchid Product Range}

1. Creative stumpy gold orchid decoration 2. Creative gold orchid industry and accessories and clothes 3. Creative gold orchid leaves and jewelry gift 4. Creative stumpy or lobate embroidery gold orchid decoration 5. Creative orchid fragrance soap products 6. Creative orchid cosmetics 7 . Creative orchid flower glass decoration 8. Creative orchid flower grating decorations etc.

\section{B. Research, Development and Design Time of Gold Orchid Products}

1) Material or raw material: Go into material processing activity of production ingredients. Local culture is also a kind of material.

2) Added value of creative design: Innovative knowledge value integrates and combines an individual industry with other industries. The process produces intelligent capital of intellectual property, patent and so on, including physical commodity's intangible service, information, application art beautification or intangible entertainment and performance and so on.

3) Added value of creative production and packaging work: Transform inputted material elements into final activities of products, including production, design, description, packaging, assembly, test and clients' activities.

4) Added value of creative marketing and sales: Guarantee that clients can know the product and purchasing activity can be realized, including advertisement and sales promotion. 
5) Added value of creative service: Relevant activities which can keep or intensify product value, including repair and installation etc.

\section{Gold Orchid and Interdisciplinary}

Research, development and design of gold orchid involve many interdisciplinary industries in the following table: materials industry, processing industry, process design industry, information industry and marketing promotion industry.

TABLE II. INTERDISCIPLINARY INDUSTRIES OF GOLD ORCHID

\begin{tabular}{|c|c|c|c|c|}
\hline $\begin{array}{l}\text { Materials } \\
\text { industry }\end{array}$ & Processing industry & Process design industry & $\begin{array}{l}\text { Information } \\
\text { industry }\end{array}$ & Marketing promotion industry \\
\hline \multirow[t]{4}{*}{$\begin{array}{l}\text { Agricultural } \\
\text { orchid } \\
\text { Metal } \\
\text { Glass } \\
\text { Grating } \\
\text { Textile line } \\
\text { Cosmetics }\end{array}$} & $\begin{array}{l}\text { Electroforming and } \\
\text { welding processing } \\
\text { Sewing and } \\
\text { embroidery } \\
\text { Printing } \\
\text { Chemical } \\
\text { engineering/extracti } \\
\text { ng } \\
\text { Cosmetics }\end{array}$ & $\begin{array}{l}\text { Stumpy gold orchid decorations orchid } \\
\text { industry and accessories and clothes gold } \\
\text { orchid leaves and jewelry gifts stumpy } \\
\text { embroidery gold orchid decorationorchid } \\
\text { fragrance soap products orchid cosmetics } \\
\text { orchid flower glass decorations orchid } \\
\text { flower grating }\end{array}$ & $\begin{array}{l}\text { Information system } \\
\text { Communication } \\
\text { network platform }\end{array}$ & $\begin{array}{l}\text { Expand marketing channels } \\
\text { Establish own brand } \\
\text { Participate in cultural and creative industry } \\
\text { expo } \\
\text { Participate in international convention and } \\
\text { exhibition } \\
\text { Improve storefront in commercial district } \\
\text { Booth technology service } \\
\text { Patent technology transaction } \\
\text { Intellectual property rights authorization }\end{array}$ \\
\hline & Company & $\begin{array}{l}\text { Company } \\
\text { Company }\end{array}$ & Company & Museum \\
\hline & Company & $\begin{array}{l}\text { A Company of three-dimensional } \\
\text { embroidery, soap patent }\end{array}$ & & \\
\hline & & Shared by school/teacher & $\begin{array}{l}\text { Shared } \\
\text { school/teacher }\end{array}$ & Marketing consultant \\
\hline
\end{tabular}

\section{Gold Orchid and Industry Relevance}

Creative industrial value chain takes the viewpoint of creating client value, disassembles activities of industry and educational circle and names it as value chain. Main activity of value chain gives play to value-added function of each phase of industry. Taking creative orchid as an instance, as achievement of flower planting and cultivation technology of Taiwan biotechnology, orchid becomes famous internationally. How to prolong its life force to produce higher value and added value becomes the theme of the whole school crossdomain talent research and development "Table III".

TABLE III. PROCESSING INDUSTRY OF GOLD ORCHID

\begin{tabular}{|c|c|c|c|c|}
\hline Agriculture & $\begin{array}{l}\text { Processing } \\
\text { industry }\end{array}$ & Design industry & Product application industry & Marketing promotion \\
\hline Biotechnology & $\begin{array}{l}\text { Chemical } \\
\text { engineering/proces } \\
\text { sing -- patent }\end{array}$ & $\begin{array}{l}\text { Commodity design } \\
\text { intellectual property rights }\end{array}$ & $\begin{array}{l}\text { Gold } \quad \text { orchid } \\
\text { clothing/jewelry/souvenir }\end{array}$ & \multirow{3}{*}{$\begin{array}{l}\text { Information industry } \\
\text { Website information platform } \\
\text { Marketing industry } \\
\text { Storefront booth in commercial circle } \\
\text { International cultural and creative expo } \\
\text { Convention and exhibition } \\
\text { Transaction in technology } \\
\text { Horizontal alliance }\end{array}$} \\
\hline $\begin{array}{l}\text { Orchid } \\
\text { cultivation }\end{array}$ & $\begin{array}{l}\text { Metal surface } \\
\text { treatment } \\
\text { electroforming } \\
\text { patent }\end{array}$ & $\begin{array}{lcc}\text { Industrial } & \text { design } & -- \\
\text { intellectual property rights } & \end{array}$ & Gold orchid gifts/giveaway & \\
\hline Other plants & Metal plus plating & $\begin{array}{l}\text { Art design -- intellectual } \\
\text { property rights }\end{array}$ & $\begin{array}{l}\text { A small amount of hand made artware } \\
\text { Volume production of cultural and } \\
\text { creative products } \\
\text { Gold orchid gifts }\end{array}$ & \\
\hline
\end{tabular}

\section{INDUSTRY-ACADEMY COOPERATION}

In order to promote development of various industries, schools cooperate with government agency, public institution, folk group and academic research organization to carry out industry-academy cooperation, including the followings: Various researches, developments and applications, including special subject research, exchange of substance, measurement and test, technology service, consultant, patent application, technology transfer, innovation incubation and so on; The school obtains stock equity by research achievement or technology. Relevant cooperation matters of various kinds of education, training, research, discussion, internship or drill. In order to develop high value creative gold orchid product research and design, the school not only needs industryacademy cooperation and exchange, namely crossing industrial circle and academic circle, but needs inter-university and interdisciplinary cooperation to intensify design and manage and make up for disadvantages. Besides interdisciplinary creative commodities, we should integrate school's marketing management and information department and combine with inter-university and inter-industry cooperation to pursue the final aim of high value creative commodities. In other words, 
it is interdisciplinary integration of different departments'

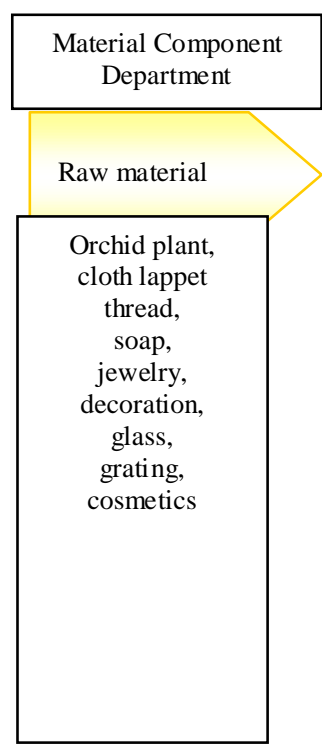

\begin{tabular}{|c|}
\hline Faculty of Technology \\
\hline Engineering \\
technology and \\
biotechnology \\
\hline Electroforming \\
technology, \\
embroidery \\
technology, \\
chemical \\
engineering \\
technology, \\
welding \\
technology, \\
component \\
assembly, glass \\
technology, \\
grating \\
technology, \\
extraction \\
technology \\
\hline
\end{tabular}

research and development as follows "Fig. 1":

Fig. 1. The process and usage of gold orchid
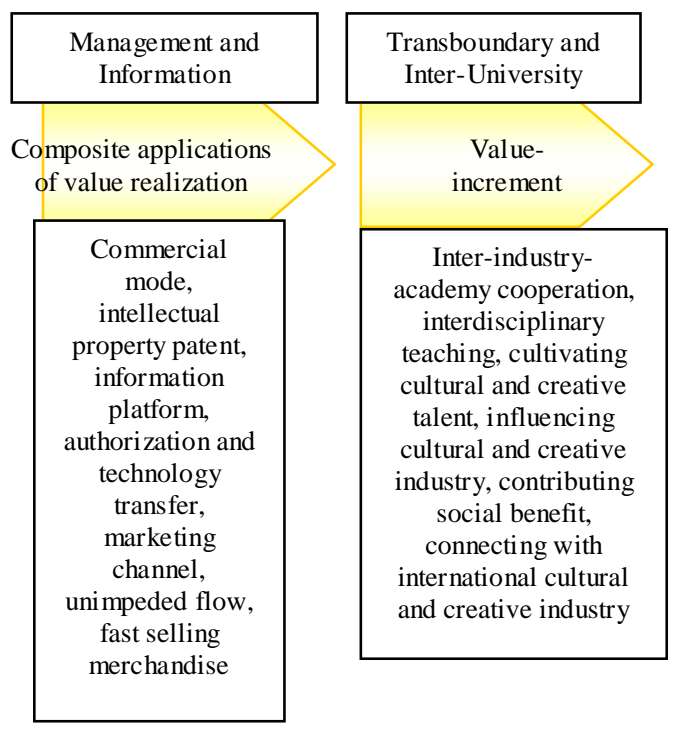

\section{A. Cultivate Interdisciplinary Talents}

The source of gold orchid product development and design takes talent cultivation as the center, namely developing interdisciplinary teaching courses in college education, obeying inputting process and output principle and discussing interdisciplinary research and development of talent cultivation and creative orchid product series as follows "Fig. 2".

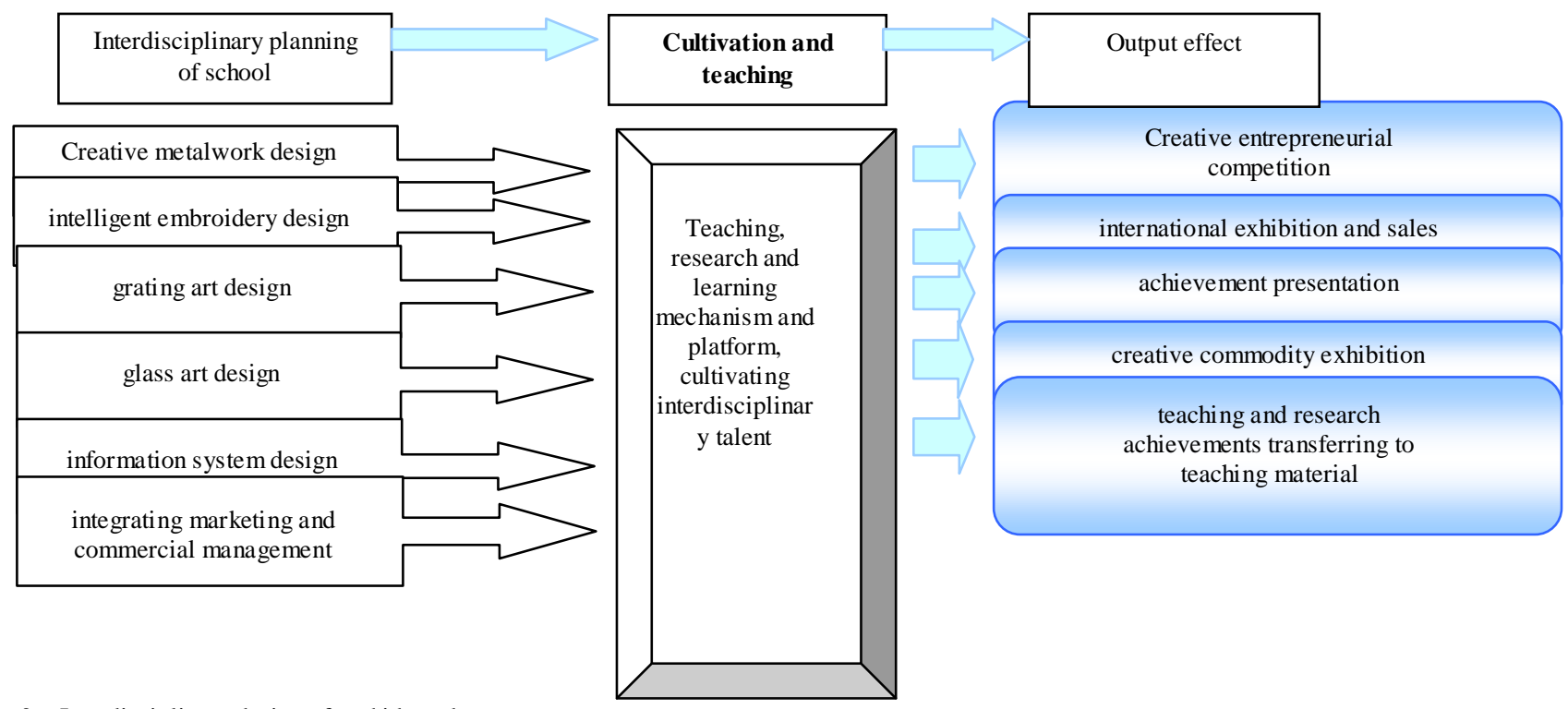

Fig. 2. Interdisciplinary design of orchid products

\section{B. Gold Orchid and Interdisciplinary Industry-Academy Cooperation}

According to viewpoints of Shi Zhenrong, enterprise value originates from two kinds of ability: The first is value creation ability and the second is value realization ability. Therefore, due to different industries and their relevant technologies, the enterprises themselves manage management ability and application of technical capacity to produce value and further create and realize value with research and development ability inside the industry or through industry-academy cooperation. However, appearance of high value needs transboundary integration ability. Take developing high value creative orchid product series as an example, we also need to refer to the following "Table IV" 
TABLE IV. PROCESS AND DEVELOPMENT OF ORCHID PlANT

\begin{tabular}{|c|c|c|c|c|c|}
\hline \multirow[t]{2}{*}{$\begin{array}{l}\text { No } \\
\cdot\end{array}$} & \multicolumn{2}{|l|}{ Industry } & \multicolumn{2}{|c|}{$\begin{array}{l}\text { Research and development of the industry or industry- } \\
\text { academy cooperation }\end{array}$} & \multirow{2}{*}{$\begin{array}{l}\text { disciplinary integration } \\
\text { Value increment }\end{array}$} \\
\hline & Raw material & $\begin{array}{l}\text { Production } \\
\text { packaging }\end{array}$ & $\begin{array}{l}\text { Value and intellectual property } \\
\text { rights }\end{array}$ & Value realization & \\
\hline 1 & Orchid plant & $\begin{array}{l}\text { Biotechnology } \\
\text { cultivation }\end{array}$ & Biotechnology value & \multirow{8}{*}{$\begin{array}{l}\text { Design and packaging } \\
\text { aesthetics } \\
\text { Value-increment } \\
\text { creative design } \\
\text { Value-increment of art } \\
\text { Value-increment } \\
\text { composite application } \\
\text { Private brand }\end{array}$} & \multirow{8}{*}{$\begin{array}{l}\text { Keep in line with international cultural } \\
\text { and creative industry through } \\
\text { interdisciplinary integration, research } \\
\text { and development, industry-academy } \\
\text { cooperation, inter-department teaching, } \\
\text { cultivating cultural and creative talent, } \\
\text { influencing cultural and creative } \\
\text { industry, contributing social benefit and } \\
\text { local creation industry }\end{array}$} \\
\hline 2 & Metal material & $\begin{array}{l}\text { Electroforming and } \\
\text { welding engineering }\end{array}$ & Engineering value & & \\
\hline 3 & Textile wire & $\begin{array}{l}\text { Embroidery and } \\
\text { sewing design }\end{array}$ & Artistry value & & \\
\hline 4 & Soap material & Chemical technology & Practical value & & \\
\hline 5 & $\begin{array}{l}\text { Cosmetics } \\
\text { material }\end{array}$ & $\begin{array}{l}\text { Chemical extracting } \\
\text { technology }\end{array}$ & Practical value & & \\
\hline 6 & Jewelry material & Sewing and handicraft & Transaction value & & \\
\hline 7 & Glass material & Glass and handicraft & Appreciation value & & \\
\hline 8 & $\begin{array}{ll}\text { Grating } & \text { paper } \\
\text { material }\end{array}$ & $\begin{array}{ll}\text { Printing } & \text { and } \\
\text { handicraft } & \end{array}$ & Appreciation value & & \\
\hline
\end{tabular}

\section{Industry-academy Cooperation Process}

Cooperation between industry and school is as follows, including research, design, development, production and marketing market "Fig. 3":

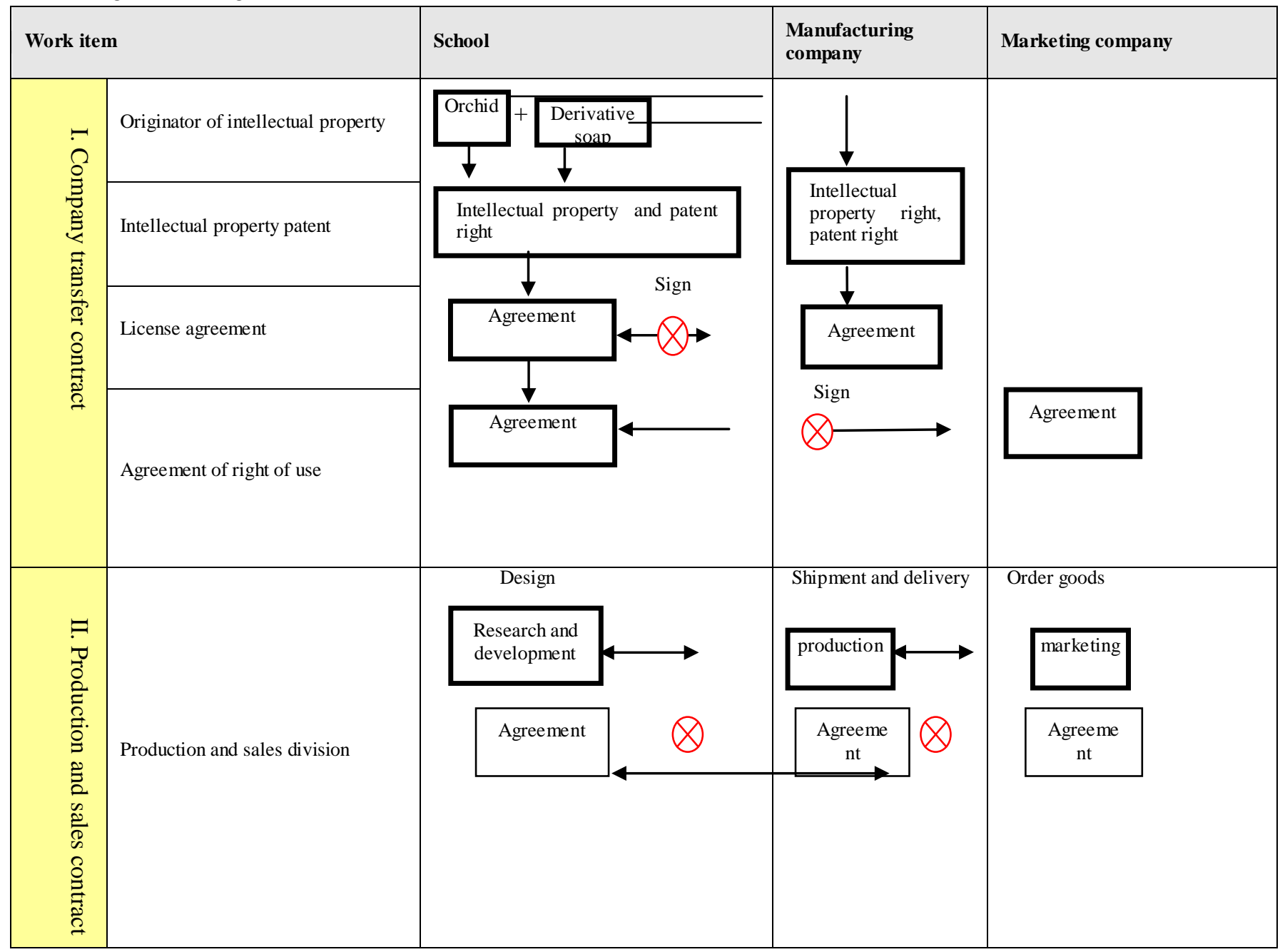

Fig. 3. The sales process of gold orchid. 
Creation value index of cultural and creative industry knowledge is as "Table $\mathrm{V}$ ":

TABLE V. EVALUATION INDEX OF INDUSTRY-ACADEMY COOPERATION

\begin{tabular}{|c|c|c|}
\hline Dimension & Quantification of target project & Qualitative index \\
\hline \multirow{7}{*}{$\begin{array}{l}\text { Creativity } \\
\text { cultivation }\end{array}$} & Number of annual participated teachers & \multirow{7}{*}{$\begin{array}{l}\text { Revise each measure and make relevant } \\
\text { incentive system. } \\
\text { Recruit outstanding practical experienced } \\
\text { scholars in design industry to make } \\
\text { speeches and give lessons in universities or } \\
\text { coach at stagnation point. } \\
\text { Invest in theme workshop studio. }\end{array}$} \\
\hline & Number of annual cultivated talents & \\
\hline & Number of campus designer certification program & \\
\hline & Number of certification of campus designer & \\
\hline & $\begin{array}{l}\text { Number of participants of designers outside } \\
\text { school }\end{array}$ & \\
\hline & $\begin{array}{l}\text { International outstanding design specialist } \\
\text { seminar }\end{array}$ & \\
\hline & Teaching material development & \\
\hline \multirow{6}{*}{$\begin{array}{l}\text { Combination of } \\
\text { theory and } \\
\text { practice }\end{array}$} & 1 Creation Competition & \multirow{6}{*}{$\begin{array}{l}\text { Carry out interdisciplinary industry- } \\
\text { academy discussion activities and provide } \\
\text { academic communication and technology } \\
\text { exchange. } \\
\text { Hold domestic and foreign interdisciplinary } \\
\text { technology exhibition or entrepreneurial } \\
\text { competition. } \\
\text { Effectively cultivate cultural and creative } \\
\text { talents under multiplex environment } \\
\text { through interdisciplinary activities }\end{array}$} \\
\hline & $\begin{array}{l}\text { Annual industry-academy cooperation amount(ten } \\
\text { thousand yuan) }\end{array}$ & \\
\hline & $\begin{array}{l}\text { Number of cases of annual industry-academy } \\
\text { cooperation }\end{array}$ & \\
\hline & Interdisciplinary discussion activity & \\
\hline & $\begin{array}{l}\text { Interdisciplinary industry-academy cooperation } \\
\text { case }\end{array}$ & \\
\hline & Number of interdisciplinary program and course & \\
\hline \multirow{6}{*}{$\begin{array}{l}\text { Production value } \\
\text { creation }\end{array}$} & Num & \multirow{6}{*}{$\begin{array}{l}\text { Effectively improve added value of } \\
\text { commodity based on } 8 \text { theme workshops } \\
\text { and } 7 \text { top teacher school studios. } \\
\text { Conduct systematic and directional research } \\
\text { and development to facilitate } \\
\text { commercialization of research and } \\
\text { development achievements. }\end{array}$} \\
\hline & of entrepr & \\
\hline & $\begin{array}{l}\text { Turnover of creation commodity(ten thousand } \\
\text { yuan) }\end{array}$ & \\
\hline & Patent count & \\
\hline & $\begin{array}{llll}\text { Number of cases of } & \text { technology } \\
\text { transfer/amount(ten thousand) } & & \\
\end{array}$ & \\
\hline & $\begin{array}{l}\text { Number of cases of achievements transformed } \\
\text { into teaching material }\end{array}$ & \\
\hline \multirow{3}{*}{$\begin{array}{l}\text { Cultural } \\
\text { creative } \\
\text { uniqueness }\end{array}$} & Number of private brand & \multirow{3}{*}{$\begin{array}{l}\text { Check existing technology development } \\
\text { routes and industrial cooperation and } \\
\text { review production value technology and } \\
\text { exchange program of various industries in } \\
\text { the region }\end{array}$} \\
\hline & $\begin{array}{l}\text { Number of creation commodity experiencing } \\
\text { internationalization }\end{array}$ & \\
\hline & Number of international exhibition & \\
\hline
\end{tabular}

\section{CONCLUSION}

The hottest topic of management in the past three years is From Leading Suppliers to Leading Consumers. Three writings arouse this topic, namely Blue Ocean Strategy, Destructive Innovation and Openness Commercial Mode. These three writings arouse attention and great response from industrial and academic field. In order to cater to these three innovative topics under discussion with different concepts, product service ideas in industry all come from customer need.

This research uses interschool cooperation and development team on biotechnology orchid product, differing from looking for solutions to problems from the route of technology development. It creates new products from innovation and value thought. As a result, it stimulates consumers to pay greater attention to value. Successful cases of industry-academy cooperation and process of elaborate fine adjustment of value delivery also influence consumers correctly choosing, proving and communicating superior value.

\section{REFERENCES}

[1] The Ministry of Culture. (2014b). "Cultural and Creative Industry Development Act." Taipei: Executive Chamber, excerpted on 2014/10/03, from http:// www.moc.gov.tw/law.do?method=find\&id=264.

[2] Wikipedia. (2015), excerpted on 2015/01/03 from http://zh.wikipedia.org/wiki/ Cultural and Creative Industry.

[3] Executive Chamber. (2010). "Cultural and Creative Industry Development Act." Taipei: Executive Chamber, excerpted on 2015/01/03, http://cci.culture.tw/cci/cci/law_detail.php?c=240\&sn=3731.

[4] Guo Qiuhuan. (2010). "the Past, Present and Future of South Korea Becoming a Great Country of Culture". Taipei: Institutional Repository, excerpted on 2015/01/03 from http://nccur.lib.nccu.edu.tw/handle/140.119/50454.

[5] Xiao Mingyu. (2014). "Study on Pierce Symbol-Triangle Theory's Application in Cultural and Creative Product Design", the unpublished doctoral dissertation of Architecture and Urban Design of the Architecture Department of Chaoyang University of Technology. Beijing China: Academic Press of Social Sciences.

[6] Smith, P. (2001) .Cultural Theory: An Introduction. Massachusetts. Blackwell Publishers Inc.pp.3-4.

[7] UNESCO. (2015) Creative Industries. Retrieved January 3, 2015, from http://www.unesco.org/new/en/santiago/culture/creative-industries/. 